\title{
THE PRIESTLY FAMILY
}

\section{Tribute to Robert J. Priestly \\ R.J. Priestly Passes at Victoria - 1952}

[The Yorkton Enterprise, 24 January 1952]

After a prolonged illness, death came to R.J. (Bob) Priestly in Veterans' Hospital at Victoria, B.C., on Friday, January 18, 1952. The former well-known Yorkton radio and newsman was laid to rest in the soldiers' plot in the Victoria cemetery on Tuesday afternoon with a number of his old Yorkton friends now living in Victoria in attendance. The funeral service was held from St. Saviour's Church, Victoria, British Columbia.

Bob Priestly was born in Toronto, June 16, 1890, and moved to Calgary in 1905 . He was educated at the Toronto public schools and spent one year at Carnegie Institute of Technology [C.I.T.]. He started a four year course at the latter in building engineering but learned how to play football, and got bitten by the newspaper bug.

He moved west with his parents to Calgary and in 1907 started to learn the plumbing and heating business in his dad's shop and graduated a full-fledged plumber in 1911. He worked as a journeyman plumber for 14 months in one shop and 18 months in another. In 1914 he enrolled at the C.I.T. in Pittsburgh. On his return to Calgary, he sold oil shares and did odd jobs of all descriptions until the summer of 1915, when he joined the C.P.R. hotel construction staff, mountain division. Returning to Calgary in the early fall, he joined the staff of The Calgary Albertan as sports editor.

He enlisted January 2, 1916, and went to England as company quartermaster sergeant, then to France as a buck private in April 1917, and returned to England on a stretcher in September of the same year. He spent seven months in hospital. He was then promoted to the rank of lance-corporal and trained M.S.A. troops [conscripts under the Military Service Act of 29 August 1917] who were just arriving in England. In September 1918, he was sent to the Canadian Officers Training Corps and was there when the fighting ceased.

On New Year's Eve, 1918, he married Isabel M. Adnams at Newbury, Berkshire, England, and shortly came to Canada. He re-entered the plumbing business with his father and remained at this work for three years. During the next four years he worked for the Alberta Pacific Grain Co., United Grain Growers and Silver Spray Brewing Co., doing free-lance writing.

In 1927 Mr. Priestly moved to Toronto to edit "Sanitary Age." Five months later he received a promotion from the Maclean's Publishing Company to edit "Sanitary Engineer." He was transferred to the Winnipeg office in February 1929, but he left this 


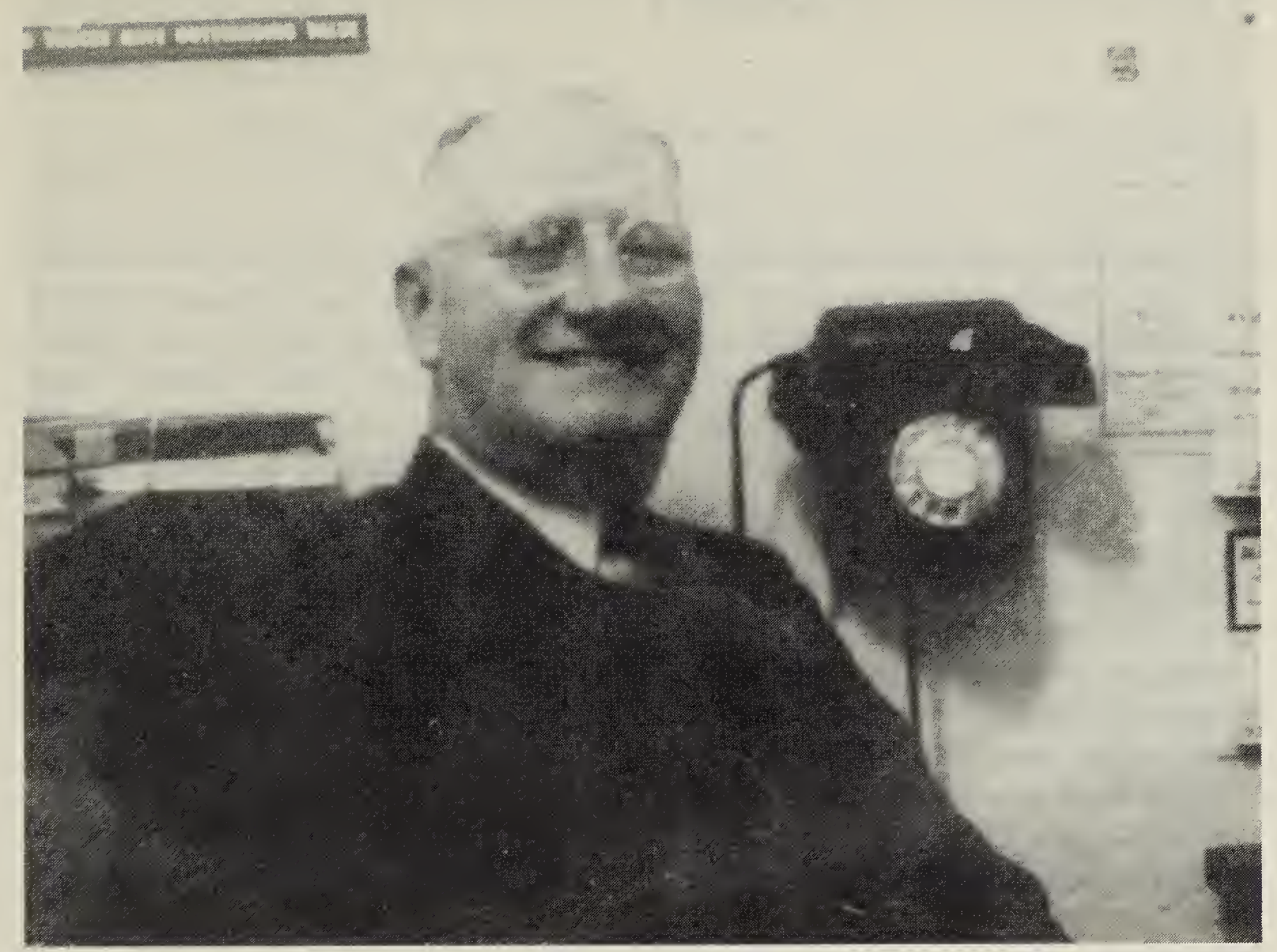

\section{R.J. Priestly}

firm in September when he joined the sports staff of the Winnipeg Tribune. The following July he accepted a position on "the desk" of the Winnipeg Free Press, remaining there until he moved to Yorkton in July 1935, succeeding Henry Savage as Sifton Bureau manager.

Mr. Priestly, in addition to his new work here, was proprietor of Bobshop which contained a lending library and tobacco shop from 1937 to 1942 , being located at what is now [1952] McKenzie Auto Equipment, Preston's Drug Store and Baker's Drugs at different times. He also handled Perth's laundry collections.

In 1942, he joined the announcing staff of Yorkton's radio station, CJGX, and was later appointed manager. In 1945, he accepted work with the Veterans' Rehabilitation Board in Regina.
Mr. Priestly's last work was the well-known Sunday afternoon feature of Regina's radio station CKCK, "Your Sunday Visitor." Through this program he won many friends among his unseen audience.

"Bob" competed in almost every branch of athletics, but specialized in football. He played, coached and refereed as well as being actively engaged in furthering sport almost all his life.

$\mathrm{He}$ is survived by his daughter, Diana, who is practicing law in Victoria, having served with the Royal Canadian Navy throughout the war; two sons, Frank, an engineer at Hamilton, Ontario, and Mike at Nanaimo, British Columbia. Mrs. Priestly predeceased her husband on April 23, 1946. 


\section{This Week in Sport}

[By KEN MAYHEW, Editor, Yorkton Enterprise, 24 January 1952]

Bob Priestly Passes The passing of our old friend Bob Priestly in the Veterans' Hospital at Victoria on Friday last removes yet another name from our list of those we held dear. At the same time it must be a happy relief for the old soldier, writer and sportsman. Life in recent years held little pleasure for one who was so fond of fun. At first we understood his remains were to be brought to Yorkton to be laid beside those of his wife, Isabel, who died here in 1946. Later it was decreed otherwise and "Old Bob" rests in the Soldiers' Plot in the Victoria cemetery.

Colorful No one can deny the statement that Bob Priestly was a colorful character. Since his return from overseas following World War I he devoted most of his life to writing, but before seeing war service he learned the trade of plumbing in Calgary.

Sportsman $\mathrm{He}$ was a keen sportsman and once served on the sport staff of the Winnipeg Tribune and later as desk editor with the Winnipeg Free Press before coming to Yorkton in the mid-summer of 1935.

Footbal Expert Bob Priestly was considered an expert on the subject of football, first as a player and later as an official. In fact it was football that caused the injury that occasioned his limp. While in Yorkton, he served as a member of the executive of the old Yorkton Terriers, and was a valued member of the Yorkton Drama League.

Familiar Figure We can see him yet hobbling along Broadway with his cane, ready to argue black was white, then burst into laughter when you proved him wrong. It was usually difficult to find him without a chew of gum or a bit of news. He had a keen sense of news, proved an excellent writer and was a true friend.

Radio Work His work in Yorkton as an announcer and station manager of CJGX won him many friends as did his philosophy on Sunday afternoon programs over CKCK, Regina, in later years.

That's "30" Yes, we'll miss "Old Bob" and will always think of the many kindnesses he did for us and others. "Old soldiers never die, they simply fade away." Rest well, fella. And that's "30" for "This Week in Sport." 


\section{Tribute to Frank D. Priestly}

[Calgary Herald, 29 July 1988]

PRIESTLY - Mr. Frank Douglas Priestly passed away in Calgary on Wednesday, July 27, 1988 following a brief illness. Born in Calgary in 1923, Mr. Priestly served with the 12th Field Regiment of the Royal Canadian Artillery as a Lieutenant during World War II and for fifteen years with the R.C.E.M.E. [Royal Canadian Electrical and Mechanical Engineers], attaining the rank of Major. He graduated with a B.Sc. in electrical engineering from the University of Alberta in 1950, joined Westinghouse Canada Inc. remaining with them until his retirement (1986) when he was Vice-President, Alberta District and of the Energy Resources Centre.

Mr. Priestly was chairman of the Business Development Committee, Calgary Chamber of Commerce; member of the Board, Calgary Economic Development Authority; Honorary Life Member of A.P.E.G.G.A. [Association of Engineers, Geologists and Geophysicists of Alberta]; member and former director of N.E.L.P.A. [Northwest Electric Light and Power Association]; former board member Industry Advisor Committee of Electrical Engineering technology of S.A.I.T. [Southern Alberta Institute of Technology]; member and past secretary of the Calgary Downtown Rotary Club; member of the Royal Alberta United Services Institute, and a member of the Anglican Church of Canada. Frank was a loving family man and loyal friend who showed dedication in his professional relationships and lively, enthusiastic and responsible concern in church, civic and service organizations. He was predeceased by his first wife Lavinia (Davies) Priestly in 1985. Mr. Priestly is survived by his sister Diana Priestly of Victoria; one brother and sister-in-law Michael and Maisie Priestly and their family of Nanaimo, B.C.; his loving wife Sheila; daughters Lavinia Welsh of Toronto and Sandra Priestly of Calgary and one granddaughter Elissa Welsh of Toronto.

\section{Tribute to Diana M. Priestly}

\section{[The Advocate 45:333-334, May 1987]}

Diana M. Priestly, who has served as Law Librarian and a member of the Faculty at both of the Province's law schools, will retire from her position at the University of Victoria on June 30 , 1987. Her association with the law and legal profession in British Columbia began in January, 1946 when she enrolled in the Special Veterans Class at the U.B.C. Faculty of Law. Prior to enrolling, she had served in the Women's
Royal Canadian Naval Service from 1943-46. While she was a student in law school, she served as Secretary of the Law Undergraduate Society. After graduation from U.B.C., she articled with the Nanaimo law firm of Leighton, Meakin and Weir. The first case in which she became involved was the textbook case of Cook v. Lewis wherein she assisted Arthur Leighton when he argued the case before the 
Court of Appeal. This case, which later went to the Supreme Court of Canada, remains as the authoritative decision on the onus of proof in a situation where the plaintiff has proven injury by reason of the conduct of one of two independent tortfeasors but the plaintiff is unable to prove which of the two tortfeasors caused the injury.

After learning, in Cook v. Lewis, about all of the dangers associated with shooting grouse at Forbes Landing and the other subtleties of practice on Vancouver Island, she entered the University of Washington. Upon obtaining her Degree of Master of Law and Librarian- ship, she returned to U.B.C. in 1953 where she served as Law Librarian and a Lecturer in the Faculty of Law until 1963. Many graduates of that era credit her with teaching the skills of legal research to a whole generation of lawyers in British Columbia. Diana fondly refers to that period of her career as the "happy years."

In 1964, she began a ten year pilgrimage through eastern Canada during which she earned the admiration and respect of lawyers, faculty, students and staff at the University of Toronto (1964-67), Osgoode Hall Law School (1967-70), the University of
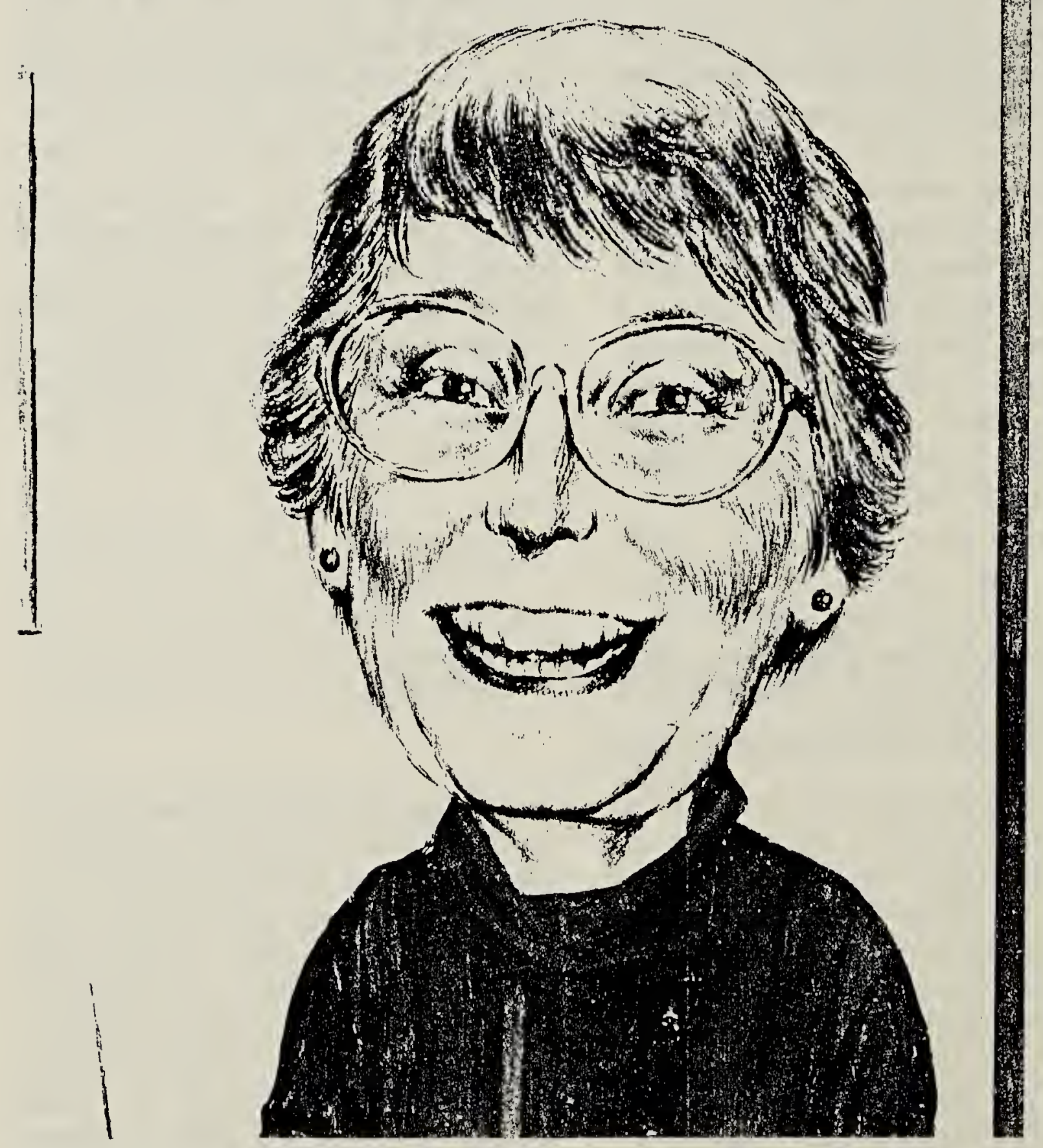

Diane M. Priestly, Law Librarian. From The Advocate, May 1987. 
Western Ontario (1970-72) and the Department of Justice, Legal Research and Planning Section, in Ottawa (197274). During this period, she gained national and international recognition as a law librarian.

In 1974, she returned to British Columbia where she became the founding Law Librarian and a Professor of Law at the University of Victoria. This was an enormous challenge when it is remembered that in 1974, the University of Victoria did not have a law library and that many law reports, periodicals and legal texts which would be required to build a law library had been out of print for decades and in some cases for centuries. Using her knowledge of law libraries and her contacts throughout the common law world, Diana met the challenge and she succeeded in assembling a first class law library collection which now consists of over 140,000 volumes. The breadth and depth of this collection has been the subject of many accolades by judges, lawyers, and academics in British Columbia and around the world.

For the past thirteen years, she has again been responsible for teaching the skills of law library re- search to another generation of lawyers from the University of Victoria. The UVic graduates and students have developed the same admiration and affection for 'Miss Priestly', as their predecessors at U.B.C. in the 1950 s and early 1960s. Students, faculty and members of the Bench and Bar have all benefited from her knowledge and appreciated the patience and understanding which she has demonstrated while assisting them with inquiries about legal materials and research.

The Board of Governors of the University of Victoria has recently recognized her outstanding achievements in developing the UVic Law Library and her contributions to librarianship and legal education in Canada by naming the law library at the University of Victoria as the "Diana M. Priestly Library."

Diana M. Priestly is a truly impressive person with a distinguished record of accomplishment and service who has a personal charm that endears her to everyone she meets.

\section{Tea and a Tribute for Diana Priestly}

\section{[The Ring, University of Victoria, June 1987]}

Faculty, students, colleagues and friends gathered on June 26 [1987] to pay tribute to Professor Diana Priestly "a very special person in the life of the University of Victoria" said President Petch at a tea held in her honour. "One of my most pleasant tasks this year was to ask the Board of Governors to name the Law Library in honour of Miss Priestly... She is a professional in the true and comprehensive sense of that term an educated person of the highest integrity, intelligence, determination and commitment to public service who retires this month as the most respected and accomplished law librarian in Common Law Canada. I raise my cup of tea to Diana Priestly, the founding librarian of the Faculty of Law, a distinguished colleague and our newest Professor Emeritus." 
Vice-President Academic Murray Fraser recalled with delight his recommendation to the Board of the "premier librarian in Canada" as the first appointee to the Law Faculty effective June 1, 1974: "Her appointment established the legitimacy of the Faculty of Law at UVic. It permitted me to recruit senior respected legal scholars. They knew that with Diana as our law librarian we were assured of success in building a first class collection. This has proved to be true. Our collection has received the most favourable comment by academics and jurists of international stature."

Fraser cited Dr. Priestly's magnificent contributions to legal educa- tion in Canada and to the University, "Fourteen-hour days, seven days a week, for many years - planning, shaping, developing the collection, hiring staff, responding to curriculum developments, participating in faculty discussions and carrying university responsibilities as well."

Expressing the sentiments of well wishers Professor Fraser thanks Diana for her leadership, encouragement, commitment and friendship. "To those of us who know you well it is no surprise that you have decided to spend the next period of your life working the peace movement and in the women's movement. We salute you and give you our very best wishes."

\section{Law Libraries in Canada: Essays to Honour Diana M. Priestly}

Edited by JOAN M. FRASER. Toronto: Carswell, 1988 $x+237$ pp. ISBN 0-459-31321-5.

[Reviewed by Michael L. Renshawe, McGill University, In: Canadian Association of Law Librarians Newsletter/Bulletin 13 (2):282-283, 1988]

This Festschrift is important for two reasons: it is an articulate and welcome addition to the relatively small body of literature on Canadian law librarianship. Certainly every law librarian should have a personal copy close at hand. More importantly, it is a professional and classy tribute to a professional, classy and very deserving lady. 


\section{R. Michael Priestly (Autobiographical Note):}

Born 3 May 1933 in Winnipeg. Came to Yorkton around the age of three. Attended Simpson School until Mother died. Lived with Mr. and Mrs. Henry Beck whilst finishing school in Yorkton.

Attended boarding school at St. John's, Winnipeg. Had one year with Père Murray at Notre Dame, Wilcox, Saskatchewan, before coming to Vancouver Island in 1949 after Dad's heart attacks. Lived in Nanaimo, British Columbia and finished high school there whilst father was a patient in the Veteran's Hospital in Victoria, where he died in 1952. Studied sheet metal work at the B.C. Institute of Technology and was employed by the first industry giant, McMillan and Bloedel.

Married Mary Thain, a Nanaimo teacner originally from Springburn, a suburb of Glasgow, Scotland, in 1961 and had four children - Jane, Alastair, Heather and lan.

Forced into early retirement because of two major open heart surgery operations. Still active as Rector's Warden of local Anglican Church. Enjoy a beautiful home overlooking the ocean with Bald Eagles soaring over and a garden full of smaller birds. Mother would have deemed it paradise.

The Prairie Landscape: There has been too much stress laid on the "bald headed" prairie and we have failed to build up, in our children, sufficient love and pride in the western landscape. Certainly Mr. Bird's lovely films were proof enough of the beauty that lies right at our very doorstep or in the poplar bluff just down the road. Comment by Mrs. Priestly on the occasion of the showing in Yorkton of Dick Bird's "Camera Trails Along Nature Trails." 